mammary artery grafts in pediatric coronary artery bypass surgery. New evidence for a "Live" conduit. Circulation 1988; 78 (Suppl. I) : I129-I139

18) Morita R., Kitamura S., Kawachi K. et al. Excercise coronary flow reserve of bilateral internal thoracic artery bypass grafts. Ann Thorac Surg 1993; 55:883-887

19) Kitamura S., Morita R., Kawachi K. et al. : Different response of coronary artery and internal mammary artery bypass grafts to ergonovine and nitroglycerin in variant angina. Ann Thorac Surg $1989 ; 47: 756-760$

20) Boylan M.J., Lytle B.W., Loop F.D. et al. : Surgical treatment of isolated left anterior descending coronary stenosis. J Thorac Cardiovasc Surg $1994 ; 107: 657-662$

21）北村惣一郎, 河内寛治, 森田隆一：内胸動脈グラ フトによる冠動脈多枝バイパス手術の早期遠隔成 績。 日心外会誌 $1992 ； 21 ： 233-237$

22) Fiore A.C., Naunheim K.S., Dean P. et al. : Results of intemal thoracic artery grafting over 15 years : single versus double grafts. Ann Thorac Surg $1990 ; 49: 202-209$

23) Suma H., Wanibuchi Y., Terada Y. et al. : The right gastroepiploic artery graft. J Thorac Cardiovasc Surg 1993; 105:615-623

24）北村惣一郎, 川田哲嗣, 森田隆一 他：冠動脈外科 の適応と成績. 臨床成人病 $1994 ； 24: 1223-1232$

\title{
double switch operation
}

房窒逆位 (atrioventricular discordance) 伴 う先天性心疾患では，多くの場合右室が体循環 心室として機能している。これらの疾患の解剖 学的修復の目的で, Mustardまたは Senning 手 術による atrial switch と, arterial switch また は右室からの肺動脈流出路再建を行うことによ $\eta$, 極力生理的な状況に近い血行動態を達成す る手術法の総称である．房室逆位を伴う代表的 な疾患は修正大血管転位 (corrected transposition of the great vessels; atrioventricular discordance, ventriculoarterial discordance) であるが，この疾患では形態的左房が三尖弁を 介して形態的右室に結合しており，形態的右室 から大動脈が起始する。このような状況ではし
ばしば三尖弁逆流が生じ，重度の心機能不全を 合併する。これに対して double switch を行う と体静脈血は三尖弁を介して右室に導かれ，そ こから新たに結合された肺動脈へ駆出される。 右室への压負荷が軽減され，また体循環は本来 の体循環心室である左室により維持されるので 心機能は多くの症例で改善される。しかしその 長期予後はいまだ明らかでなく,手術侵襲, atrial switchに続発する上室性不整脈，また arterial switchに扩ける冠動脈の処理など技術面での問 題点も残されており，いまだある程度限られた 症例に適応とされる。より生理的な心内修復と いう面からは，さらに適応の拡大，手術成績の 向上が期待される。

(高橋長裕) 